\title{
Declined expressing mRNA of beta- defensin 108 from epididymis is associated with decreased sperm motility in blue fox (Vulpes lagopus)
}

Ping Wu${ }^{\dagger}$, Tao-lin Liư ${ }^{\dagger}$ Ling-ling Li, Zhi-ping Liu, Li-hong Tian ${ }^{*}$ and Zhi-jun Hou ${ }^{*}$

\begin{abstract}
Background: Fecundity is important for farm blue fox (Vulpes lagopus), who with asthenospermia have be a problem in some of farms in China. A key symptom of asthenospermia is decreased sperm motility. The decreased secreting beta-defensin108 (vBD108) of blue fox is speculated be related to asthenospermia. To clarify this idea, the mRNA expression of $V B D 108$ in testis and epididymis of blue foxes with asthenospermia were detected and compared to the healthy one. The antibody was prepared and analyzed by immunohistochemistry.

Results: The VBD108 in testis and epididymis was found both in blue fox with asthenospermia and healthy group by the method of immunohistochemistry. The expression of $v B D 108$ mRNA in testes $(P<0.05)$ and epididymal corpus $(P<0.0001)$ in asthenospermia group was lower than that in healthy group.

Conclusions: These results suggested that VBD108 deficiency may related to blue fox asthenospermia. Meanwhile, the study on the blue fox VBD108 provides a hopeful direction to explore the pathogenesis of blue fox asthenospermia in the future.
\end{abstract}

Keywords: Vulpes lagopus, epididymis, vBD108, asthenospermia, sperm motility

\section{Background}

$\beta$-defensins, well known cationic antimicrobial peptide rich in cysteine [1-4], belonging to a family of hostdefense peptides, produced by multiple epithelial tissues and immune cells, played an important role in the innate immune response [5, 6]. Although most of the studies on $\beta$-defensins focused on their antibacterial and antitumor activities, there is growing evidence that $\beta$ defensins play a special role on motility of sperm in the epididymal of mammals $[7,8]$.

\footnotetext{
*Correspondence: tianlihong1122@sina.com; houzhijundz@163.com †Ping Wu and Tao-lin Liu contributed equally to this work. College of Wildlife and Protected Area, Northeast Forestry University, Harbin, China
}

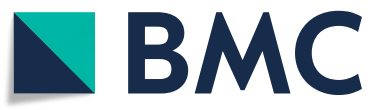

(C) The Author(s). 2020 Open Access This article is licensed under a Creative Commons Attribution 4.0 International License, which permits use, sharing, adaptation, distribution and reproduction in any medium or format, as long as you give appropriate credit to the original author(s) and the source, provide a link to the Creative Commons licence, and indicate if changes were made. The images or other third party material in this article are included in the article's Creative Commons licence, unless indicated otherwise in a credit line to the material. If material is not included in the article's Creative Commons licence and your intended use is not permitted by statutory regulation or exceeds the permitted use, you will need to obtain permission directly from the copyright holder. To view a copy of this licence, visit http://creativecommons.org/licenses/by/4.0/. The Creative Commons Public Domain Dedication waiver (http://creativecommons.org/publicdomain/zero/1.0/) applies to the data made available in this article, unless otherwise stated in a credit line to the data.
The addition of cauda epididymal fluid (CEF) of cattle containing $\beta$-defensin 126 (BBD126) can significantly improve the motility of bovine spermatozoa [9]. The results of some studies suggested that human $\beta$-defensin 1 $(h B D-1)$ can affect the quality of sperm and improve sperm motility when exogenously added $[10,11]$. Inhibition of the expression of Bin1b, a rat epididymisspecific $\beta$-defensin with antimicrobial activity [12], resulted in a decrease in the binding of Bin1b to sperm and a significant decrease in sperm motility and progressive movement [8]. The epididymal specific $\beta$-defensin 15 (Defb15) was down regulated in vivo, which would result significantly decreased the total motility and progressive motility of rat spermatozoa [7]. 
Some farm blue fox with low sperm motility was paid attention and it always be called asthenospermia [10]. As the $\beta$-defensin is involved in the acquisition of sperm motility, the asthenospermia of blue fox may be related to the decrease of $\beta$-defensin secretion was suspected. The object of this study is to confirm if the $\beta$-defensin 108 , especially in testis and epididymis, is related to the sperm motility.

\section{Results}

\section{Detection of $v B D 108$ protein in testis and epididymis}

These animals did not use other drugs or other experiments before the experiment. In the immunohistochemical experiment, three healthy blue foxes (3/5) and three blue foxes with asthenospermia (3/5) were used. The reason is that about half of the samples were randomly selected for immunohistochemical detection. The results of immunohistochemical detection of $v B D 108$ were shown in Fig. 1. Staining of the testis and caput, corpus and cauda of the epididymis from the control group without primary antibody was negative. Brown coloration indicative of positive staining was found both in the testis, caput epididymis, corpus epididymis as well as in the cauda epididymis of the asthenospermia blue fox and healthy one compare to the control group.

\section{Detection of mRNA expression level of $v B D 108$ in testis and epididymis of asthenospermia and the healthy blue fox}

The results of immunohistochemistry showed that there was a difference in the expression of $v B D 108$ between healthy blue fox and asthenospermia blue fox. We used qPCR technique to quantitatively analyze the expression levels of $v B D 108$ in testes, and caput, corpus and cauda of epididymis of asthenospermia blue fox and the healthy one. The expression level of $v B D 108$ mRNA in testes and epididymis of blue fox was analyzed as shown in Fig. 2. We found that the relative expression of $v B D 108$ both in testes $(P<0.05)$ and corpus epididymis $(P<0.0001)$ of healthy blue fox was significantly higher than that of blue fox with asthenospermia. Among the healthy fox and asthenospertic one, the difference of

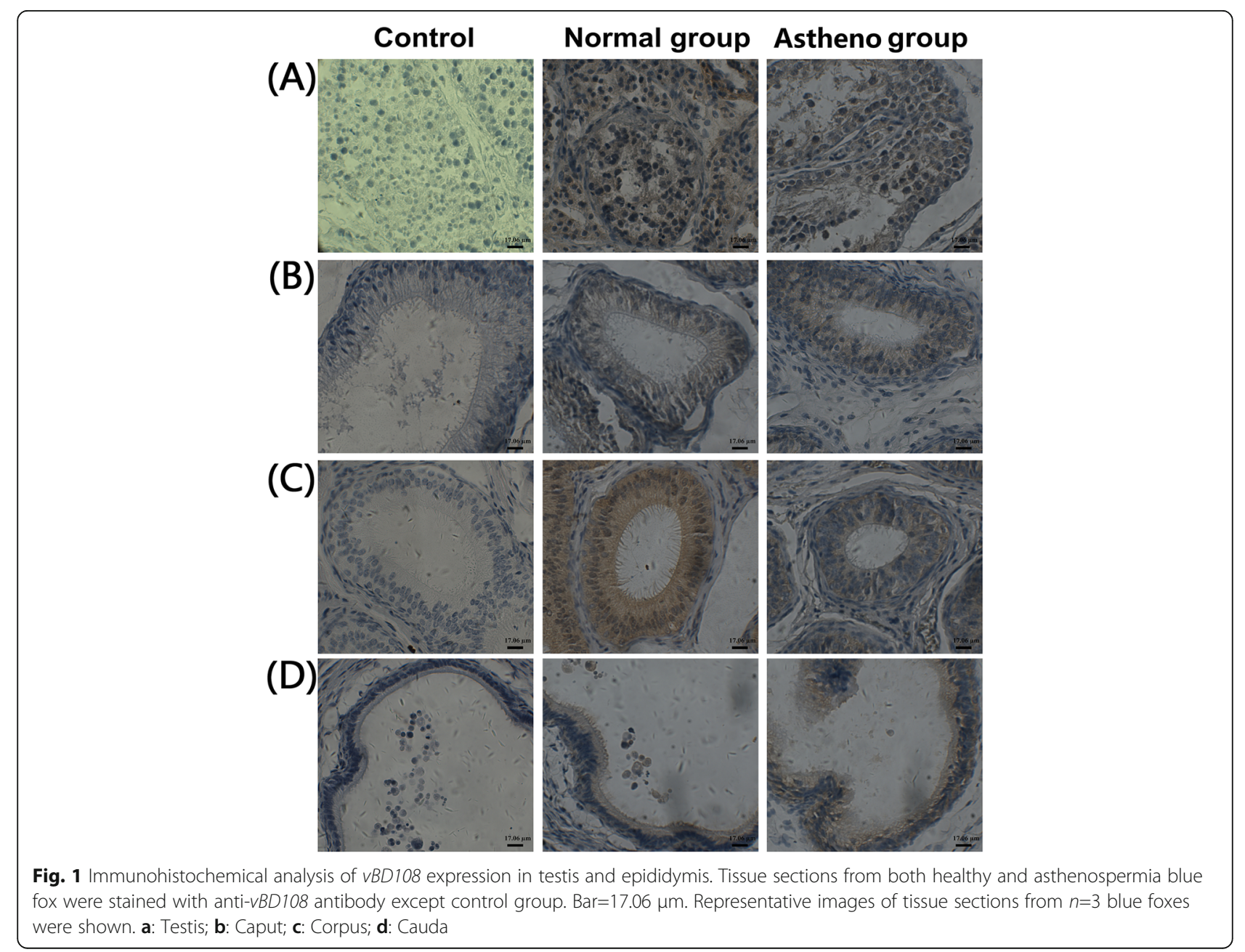




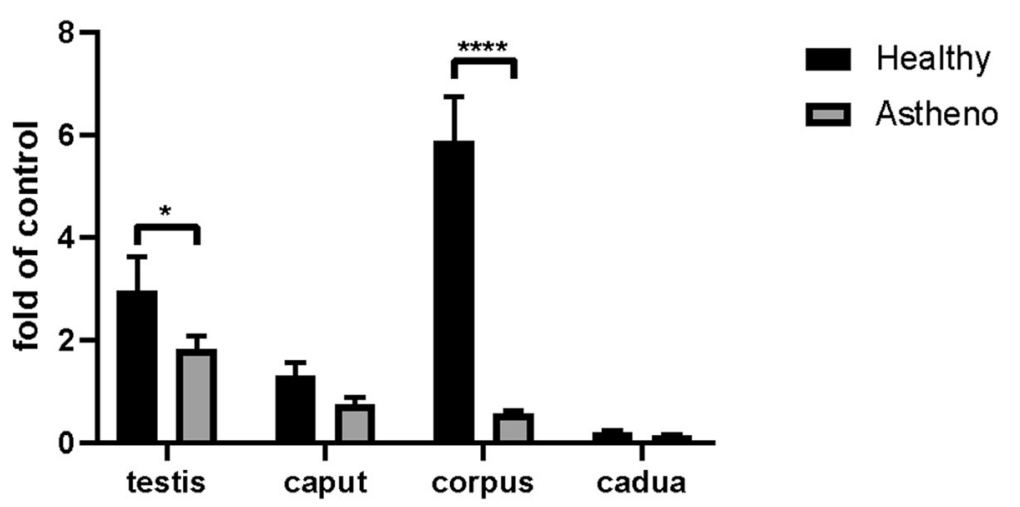

Fig. 2 Relative expression of $V B D 108$ in testis and epididymis of asthenospermia and healthy blue fox. Data are expressed as the mean $\pm S D, n=3$. The difference between averages is determined by using Sidak's multiple comparisons test ( $\left.^{*}, P<0.05 ; * * *, P<0.0001\right)$

$v B D 108$ in corpus of epididymis is especially apparently $(P<0.0001)$.

\section{Discussion}

The epididymal lumen environment is an androgen response organ composed of specific ions, small organic molecules and proteins responsible for sperm maturation and storage [13]. In addition to $\beta$-defensin, androgen also plays an important role in several physiological processes of epididymis. Several studies have reported that androgens may regulate some $\beta$-defensins [14]. Two mouse $\beta$-defensins (Defb41 and Defb42) are regulated by androgens by Q-RT-PCR and in situ hybridization [15]. Sperm-associated antigen $11 \mathrm{~A}$ is expressed exclusively in the principal cells of the mouse caput epididymis in an androgen-dependent manner [16]. Human epididymis specifically expresses $\beta$-defensin $118 \quad$ (DEFB118) (formerly ESC42) is regulated by androgen [17]. Six genes (Defb18, 19, 20, 39, 41 and 42) of mouse epididymal $\beta$-defensin were identified by bilateral orchiectomy and androgen supplementation, which were completely regulated by androgen [18]. Moreover, the time difference of seasonal expression is also the characteristic of $\beta$-defensin. The mRNA level of SPAG11A in the epididymis of wild ground squirrels in breeding season was significantly higher than that in non-breeding season [16]. A lot of studies have shown that the expression of $\beta$ defensin in testes and epididymis of different species (rat, mouse, sheep, goat) is time-dependent. The expression of sheep Defb124 gene in sheep testes and epididymis and the goat beta-defensins 104a in the epididymis have age differences $[19,20]$. Likewise, the expression of $\beta$-defensins (Defb15 and -49) in rat epididymis and Defb41 in mouse testes are different during postnatal development $[7,15,21]$. To sum up, we speculate that $v B D 108$ may have the same differences in age distribution and androgen dependence and seasonal expression as these $\beta$-defensins. However, these functions of $v B D 108$ still need to be tested by experiments in the future.

A great number of studies have shown that $\beta$-defensin is involved in antimicrobial activity and regulating immune host $[5,22]$. Loss of $\beta$-defensin gene expression can lead to asthenospermia, which is usually associated with low sperm motility $[10,23]$. Sperm motility is considered to be one of the most important sperm functions affecting natural conception [24]. More and more studies have shown that mammalian $\beta$-defensin has an effect on sperm function. It is worth noting that after sperm are produced from the testis, they gain their motility and fertilization ability through the epididymis, which is called sperm maturation [13, 25]. Biology generally divides the epididymis into caput, corpus and cauda $[9,26$, 27], which created unique and dynamic physiological environment provides conditions for sperm maturation [28-31]. A variety of region-specific epididymal $\beta$ defensins contribute to different microenvironments of epididymal sperm maturation in different segments were found [6]. The expression of $v B D 108$ protein in epididymis of blue fox with asthenospermia have an apparently difference compare with the healthy one, it suggests that $v B D 108$, as a molecule of epididymal microenvironment, may be involved in the acquisition of sperm motility. This view is supported by some reports. A rat epididymal specific $\beta$-defensin $(\operatorname{Bin} 1 b)$ [12] can bind to sperm heads in different regions of the epididymis in different binding modes has been reported. Moreover, Bin1b is considered to be related to epididymal sperm maturation [8]. Human $\beta$-defensin 1 (DEFB1) interacts with chemokine receptor type 6 (CCR6) in spermatozoa, triggering $\mathrm{Ca}^{2+}$ mobilization, which is key for sperm motility [10]. $\beta$-defensin DEFB126, a multifunctional glycoprotein, is adsorbed to the sperm surface during epididymal maturation [32]. All in all, these findings suggest that members of $v B D 108$ may be involved not only in antibacterial and 
host immunity, but also in the regulation of sperm motility.

Although our experimental results found that $v B D 108$ may be related to azoospermia in blue foxes, we need more experiments to determine the role of $v B D 108$ in sperm motility and male reproduction. We plan to clarify this problem through several aspects in following works. Firstly, $v B D 108$ antibody or $v B D 108$ protein are co-cultured with sperm to observe the changes of sperm motility. Secondly, the expression of $v B D 108$ gene in the epididymis of blue fox was knocked down by RNAi technique, and the changes of the binding ability of $v B D 108$ to sperm and the binding ability between sperm and ovum were analyzed. Finally, mating experiments were conducted to evaluate the changes in fertility of male blue fox with down-regulated $v B D 108$.

\section{Conclusions}

The results of this study demonstrate that low $v B D 108$ in corpus of epididymis was associated to asthenospermia and might be causal linked to low sperm motility. Meanwhile, the study on the blue fox $v B D 108$ provides a hopeful direction to explore the pathogenesis of blue fox asthenospermia in the future.

\section{Methods}

\section{Animals and tissue collection}

The five healthy and eight asthenospermia blue foxes are provided by Harbin Hualong Blue Fox breeding Co., Ltd. The age of the animals were two years old. The weight of the animals was from 17 to $22 \mathrm{~kg}$. These experimental animals were all male. $\mathrm{Wu}$ et al. used sperm motility analysis system (IVOS) to detect sperm motility in fresh semen. Sperm forward motility is less than $50 \%$ or fast straight forward movement is less than $25 \%$, which is called low sperm motility, also known as asthenospermia [33]. According to the International Animal Welfare Law, the blue fox was euthanized by intravenous injection of excessive pentobarbital sodium. The testes, and caput, corpus and cauda of epididymes were collected in April 2017 in College of Wildlife and Protected Area, Northeast Forestry University, Harbin, China. The samples were soaked in RNA preservation solution and stored at $-80^{\circ} \mathrm{C}$. In addition, the tissue samples of each sample were cut into tissue blocks of $0.5 \mathrm{~cm} \times 0.5 \mathrm{~cm} \times$ $0.2 \mathrm{~cm}$ and fixed in $4 \%$ neutral formaldehyde fixation solution. Four SPF New Zealand rabbits were purchased from the Harbin Veterinary Research Institute, CAAS. The age of the rabbits ranged from 1 to 1.5 years and the weight of the animals were from 1.45 to $1.55 \mathrm{~kg}$. Rabbits were fed with rabbit feed (SPF experimental rabbit feed) in $37^{\circ} \mathrm{C}$ laboratory animal room. Two rabbits were kept in each cage and they had free access to water. The rabbits were euthanized after excessive intravenous injection of pentobarbital sodium at the end of the experiment.

\section{Preparation of polyclonal antibody against rabbit VBD108} A custom monoclonal antibody specific for $v B D 108$ was commercially generated by Genscript using a standard protocol. The synthesized $v B D 108$ protein was diluted with sterilized PBS (Takara, Dalian) buffer and emulsified with Freund Adjuvant (Takara, Dalian) at a volume ratio of $1: 1$, and then used for inoculation. $1 \mathrm{ml}$ of immune antigen emulsion $(0.25 \mathrm{mg} / \mathrm{ml})$ in $200-300 \mu \mathrm{l}$ per each site was injected into the abdominal cavity of rabbits. Operate in the same way every 14 to 16 days. Rabbits were immunized three times, the first one was immunized with Freund complete adjuvant, and the last two times, Freund incomplete adjuvant was selected [34]. After the third immunization, the blood was collected from the auricular vein on the 12th day and the serum was separated.

\section{Enzyme-linked immunosorbent assay}

The titer of serum was determined by indirect ELISA [35] with respective pre-immunized serum as negative control. In short, the gradient diluted $v B D 108$ was used to coat the enzyme labeling plate transversely, and the gradient diluted rabbit $v B D 108$ positive serum and negative serum were added longitudinally to the enzyme labeling plate. The absorbance value was measured and the optional coating concentration of $v B D 108$ and the best working concentration of serum were determined. Then the antibody titer of $v B D 108$ was determined by the same method with the determined optimal antigen coating concentration. The ratio of OD490nm in positive serum to OD490nm in negative serum was between 1.5 and 3.0, which was the zero point of positive reaction, and the corresponding serum dilution was the antibody titer of serum.

\section{Immunohistochemical detection of vBD108 in testis and epididymis of blue fox with asthenospermia and the healthy one}

The samples of blue foxes with asthenospermia $(n=3)$ and the healthy one $(n=3)$ were used by immunohistochemistry. The fixed tissue samples were dehydrated with different concentrations of ethanol, the dehydrated tissues were treated with anhydrous ethanol and xylene 1:1 mixture for $30 \mathrm{~min}$, and xylene solution $20 \mathrm{~min}$ for twice. After transparent operation, the tissue needs to be soaked in wax for 3 hours and embedded 3-5 $\mu \mathrm{m}$ thick slices, fixed on chromic acid-treated slides, spread them in a pool at $30{ }^{\circ} \mathrm{C}$, bake at $37{ }^{\circ} \mathrm{C}$ overnight or $60^{\circ} \mathrm{C}$ for 2 hours. After tissue dewaxing, the slides were heated in sodium citrate at $98{ }^{\circ} \mathrm{C}$ in $10 \mathrm{~min}$ for antigen repair, $3 \%$ $\mathrm{H}_{2} \mathrm{O}_{2}$ for 10 min, 5 min washing for 3 times, $1 \times$ PBS for 
5 minutes. Goat serum was diluted 10 times with $1 \times$ PBS and sealed for one hour. The primary antibody was diluted according to 1:1000, each piece was $100 \mu \mathrm{l}$ (wax circle), overnight at $4{ }^{\circ} \mathrm{C}$ (recovery of the primary antibody), and 5 min washed with $1 \times$ PBS for three times after incubation.

The slides were incubated with the second antibody (HRP labeled goat anti-rabbit IgG) $37^{\circ} \mathrm{C}$ for 1 hour with the diluent in the DAB chromogenic kit (Takara, Dalian). $\mathrm{H}_{2} \mathrm{O}_{2}$ was added to the diluted DAB chromogenic solution according to the ratio of 1:1000, and then added to the glass slide for color development. Re-dye with hematoxylin for one minute, add dilute hydrochloric acid to return to red, and then return to blue in light ammonia water. Finally, it was dehydrated, sealed with neutral gum and observed under microscope. Controls were subjected to the same procedure except without adding primary antibody.

\section{Acquisition of organizational CDNA}

According to the operation instructions of Trizol Reagent kit (BioTeke, Beijing), the total mRNA, nucleic acid and protein analyzer NanoDrop-2000 (Beijing) was used to determine the concentration and purity of total RNA, and then the adjusted concentration was about 0.5 $\mu \mathrm{g} / \mathrm{ml}$. According to canine $\beta$-defensin 108 gene (accession: XM_003432123) in NCBI database, degenerate primer was designed using primer 5.0. The coding sequence of $v B D 108$ was amplified by the following primers: forward primer F: 5'- GAAGCCKT GTCTGCCTCTG - 3' and reverse primer R: 5'- GATC ATTCCTTGGGTGTAG - 3'. Reverse transcription was performed according to the instructions of HiScrip ${ }^{\circ}$ II Q RT SuperMix for qPCR (+ gDNA wiper) kit (Vazyme, Nanjing). The first step was as follows: $20 \mu \mathrm{l}$ total reaction system, including $4 \times$ gDNA wiper Mix $4 \mu \mathrm{l}, 12 \mu \mathrm{l}$ total RNA extracted from each tissue, $42{ }^{\circ} \mathrm{C}$ for $2 \mathrm{~min}$. The second step: $5 \times$ HiScript II qRT SuperMix II $4 \mu$ l, the first step reaction solution $16 \mu \mathrm{l}$, reverse transcription conditions: $50{ }^{\circ} \mathrm{C}$ for $15 \mathrm{~min}, 85^{\circ} \mathrm{C}$ for $5 \mathrm{sec}$, products were stored at $-20{ }^{\circ} \mathrm{C}$.

\section{qPCR}

In order to detect the expression of $v B D 108$ in testis and epididymis of blue fox, the primers for qPCR detection of fox $v B D 108$ gene (F: 5'-CTCGCCCTGCTCTTCTTT CT-3', R: 5'-CGTGGCCATTTAAACACCTC - 3') were designed according to canine $\beta$-defensin 108 gene (accession: XM_003432123) in NCBI database. According to the reaction system and reaction conditions of AceQ qPCR SYBR Green Master Mix kit (Vazyme, Nanjing), real-time quantitative PCR reaction was carried out. The cDNA obtained in the experiment was used as a template, and the qPCR detection primers mentioned above were added to the 96-well plate (with repetitive holes) dedicated for fluorescent quantitative PCR, and the following reagents were added at one time. The upstream and downstream primers were respectively $1 \mu$ l, SYBR Green Master Mix (2×) $7.5 \mu \mathrm{l}$, cDNA solution $3 \mu \mathrm{l}$, $\mathrm{ddH}_{2} \mathrm{O}$ supplement to the final reaction volume of $16 \mu \mathrm{l}$. GAPDH was used as the internal reference, the sequence of it was amplified by the following primers: the forward primer F: 5'- AACATCATCCCTGCTTCCAC - 3' and the reverse primer R: 5'- ATGCCTGCTTCACTACCT TCTT -3 . The fluorescence quantitative results were all processed by $2^{-\triangle \Delta C T}$ method, and the relative expression of target gene was analyzed by GraphPad Prism Version 8.0.2.

\section{Statistical analysis}

We performed statistical analysis using GraphPad Prism Version 8.0.2. Results are shown as mean \pm standard deviation. Data correlation analysis was performed between groups. We considered results to be significant at $P<$ 0.05 .

\section{Abbreviations}

mRNA: Messenger ribonucleic acid.; CEF: Cauda epididymal fluid; qPCR: Realtime Quantitative PCR Detecting System; CCR6: Chemokine receptor type 6; RNA: Ribonucleic acid; SPF: Specific pathogen free; CAAS: Chinese Academy of Agricultural Sciences; $\mathrm{H}_{2} \mathrm{O}_{2}$ : Hydrogen peroxide; PBS: Phosphate buffered solution; ELISA: Enzyme-linked immunosorbent assay; cDNA: Complementary deoxyribonucleic acid; GAPDH: Glyceraldehyde-3-phosphate dehydrogenase; SD: Standard deviation

\section{Acknowledgements}

Not applicable.

\section{Authors' contributions}

$\mathrm{LT}$ and $\mathrm{ZH}$ contributed to conception and design of the study. $\mathrm{ZL}, \mathrm{TL}$ is responsible for sample collection. TL participated in the experimental procedures including immunohistochemistry. WP and LL are responsible for data analysis and interpretation and manuscript writing and revisions. All authors have read and approved the final product. As joint first authors, both $\mathrm{PW}$ and $\mathrm{TL}$ contributed equally to the research work.

\section{Funding}

This research was supported by the National Key Research and Development Program of China (No.2018YFD0502201) and the Fundamental Research Funds for the Central Universities (NO.2572014CA02). This funding body provided monetary support only and did not have any input into the design of the study, collection, analysis, and interpretation of data.

\section{Availability of data and materials}

The datasets generated and/or analysed during the current study are available in the GenBank (https://www.ncbi.nlm.nih.gov/nuccore/XM_ 003432123) and the accession number is XM_003432123.

\section{Ethics approval and consent to participate}

All experimental designs and animals handling were approved by the Laboratory Animal Management and Ethics Committee of Northeast Forestry University (2020023)

\section{Consent for publication}

Not applicable.

Competing interests

The authors declare that they have no competing interests. 
Received: 7 July 2020 Accepted: 26 November 2020

Published online: 07 January 2021

\section{References}

1. Aram R, Chan PTK, Cyr DG. Beta-defensin126 is correlated with sperm motility in fertile and infertile men. Biol Reprod. 2019;102(1):92-101.

2. Dorin JR, Barratt CL. Importance of $\beta$-defensins in sperm function. Mol Hum Reprod. 2014;20(9):821-26

3. Ribeiro CM, Silva EJ, Hinton BT, Avellar MC. $\beta$-defensins and the epididymis: contrasting influences of prenatal, postnatal, and adult scenarios. Asian J Androl. 2016;18(2):323-28.

4. White SH, Wimley WC, Selsted ME. Structure, function, and membrane integration of defensins. Curr Opin in Struct Biol. 1995:5(4):521-27.

5. Ganz T. Defensins: antimicrobial peptides of innate immunity. Nat Rev Immunol. 2003;3(9):710-20.

6. Yamaguchi $Y$, Nagase $T$, Makita $R$, Fukuhara $S$, Tomita $T$, Tominaga $T$, Kurihara $\mathrm{H}$, Ouchi Y. Identification of multiple novel epididymis-specific beta-defensin isoforms in humans and mice. J Immunol. 2002;169(5):2516-23.

7. Zhao Y, Diao H, Ni Z, Hu S, Yu H, Zhang Y. The epididymis-specific antimicrobial peptide $\beta$-defensin 15 is required for sperm motility and male fertility in the rat (Rattus norvegicus). Cell Mol Life Sci. 2011;68(4):697-708.

8. Zhou CX, Zhang YL, Xiao L, Zheng M, Leung KM, Chan MY, Lo PS, Tsang LL, Wong HY, Ho LS, Chung YW, Chan HC. An epididymis-specific $\beta$-defensin is important for the initiation of sperm maturation. Nat Cell Biol. 2004;6(5): 458-64

9. Fernandez-fuertes B, Narciandi F, Ofarrelly C, Kelly AK, Fair S, Meade KG, Lonergan P. Cauda Epididymis-Specific Beta-Defensin 126 Promotes Sperm Motility but Not Fertilizing Ability in Cattle. Biol Reprod. 2016:95(6):122.

10. Diao R, Fok KL, Chen H, Yu MK, Duan Y, Chung CM, Li Z, Wu H, Li Z, Zhang $\mathrm{H}$, Ji Z, Zhen W, Ng CF, Gui Y, Cai Z, Chan HC. Deficient human $\beta$-defensin 1 underlies male infertility associated with poor sperm motility and genital tract infection. Sci Transl Med. 2014;6(249):249ra108.

11. Zupin L, Polesello V, Martinelli M, Luppi S, Giolo E, Zito G, Romano F, Segat $L$, Crovella S, Ricci G. Human $\beta$-defensin 1 in follicular fluid and semen: impact on fertility. J Assist Reprod Genet. 2019;36(4):787-97.

12. Li P, Chan HC, He B, So SC, Chung YW, Shang Q, Zhang YD, Zhang YL. An antimicrobial peptide gene found in the male reproductive system of rats. Science. 2001;291(5509):1783-85.

13. Johnston DS, Jelinsky SA, Bang HJ, DiCandeloro P, Wilson E, Kopf GS, Turner $\Pi$ T. The mouse epididymal transcriptome: transcriptional profiling of segmental gene expression in the epididymis. Biol Reprod. 2005;73(3):40413.

14. Oh J, Lee J, Woo JM, Choi E, Park I, Han C, Baek N, Lee H, Kim DH, Cho C. Systematic identification and integrative analysis of novel genes expressed specifically or predominantly in mouse epididymis. BMC Genom. 2006;7:314

15. Jalkanen J, Huhtaniemi I, Poutanen M. Discovery and characterization of new epididymis-specific beta-defensins in mice. Biochim Biophys Acta. 2005:1730(1):22-30.

16. Yu W, Zhang Z, Liu P, Yang X, Zhang H, Yuan Z, Han Y, Weng Q. Seasonal expressions of SPAG11A and androgen receptor in the epididymis of the wild ground squirrels (Citellus dauricus Brandt). Eur J Histochem. 2020;64(2): 3111.

17. Yenugu S, Hamil KG, Radhakrishnan Y, French FS, Hall SH. The androgenregulated epididymal sperm-binding protein, human beta-defensin 118 (DEFB118) (formerly ESC42), is an antimicrobial beta-defensin. Endocrinology. 2004;145(7):3165-73.

18. Hu SG, Zou M, Yao GX, Ma WB, Zhu QL, Li XQ, Chen ZJ, Sun Y. Androgenic regulation of beta-defensins in the mouse epididymis. Reprod Biol Endocrinol. 2014;12:76

19. Li Z, Zhang GL, Guo LN, Zhang CX. Expression of Defb124 Gene in Testis, Epididymidis at Different Stages of Sheep. China Herbivore Science. 2014; 34(04):5-8. (in Chinese)

20. Guo LN, Zhang GL, Ren YS, Jiang YS, Liu WZ, Zhang CX: Localization and expression character of Beta-Defensins 104a in different days of male goat testis and epididymis. J SHANXI AGRIC, UNIV(Natural Science Edition). 2017; 37(12):866 - 71. (in Chinese).

21. Patil AA, Cai Y, Sang Y, Blecha F, Zhang G. Cross-species analysis of the mammalian beta-defensin gene family: presence of syntenic gene clusters and preferential expression in the male reproductive tract. Physio Genomics. 2005;23(1):5-17.
22. Hall SH, Hamil KG, French FS. Host defense proteins of the male reproductive tract. J Androl. 2002;23(5):585-97.

23. Curi SM, Ariagno Jl, Chenlo PH, Mendeluk GR, Pugliese MN, Sardi Segovia LM, Repetto HE, Blanco AM. Asthenozoospermia:analysis of a large population. Arch of Androl. 2003;49(5):343-49.

24. Hunault CC, Habbema JD, Eijkemans MJ, Collins JA, Evers JL, te Velde ER. Two new prediction rules for spontaneous pregnancy leading to live birth among subfertile couples, based on the synthesis of three previous models. Hum Reprod. 2004;19(9):2019-26.

25. Cooper TG. Sperm maturation in the epididymis: a new look at an old problem. Asian J Androl. 2007:9(4):533-9.

26. Chauvin TR, Griswold MD. Androgen-regulated genes in the murine epididymis. Biol Reprod. 2004;71(2):560-69.

27. Jelinsky SA, Turner TT, Bang HJ, Finger JN, Solarz MK, Wilson E, Brown EL, Kopf GS, Johnston DS. The rat epididymal transcriptome: comparison of segmental gene expression in the rat and mouse epididymides. Biol Reprod. 2007;76(4):561-70.

28. Breton S, Nair AV, Battistone MA. Epithelial dynamics in the epididymis: role in the maturation, protection, and storage of spermatozoa. Andrology. 2019; 7(5):631-43.

29. Cornwall GA. Role of posttranslational protein modifications in epididymal sperm maturation and extracellular quality control. Adv Exp Med Biol. 2014; 759:159-80

30. Hinton BT, Palladino MA. Epididymal epithelium: Its contribution to the formation of a luminal fluid microenvironment. Microsc Res Tech. 1995; 30(1):67-81.

31. Jervis KM, Robaire B. Dynamic changes in gene expression along the rat epididymis. Biol Reprod. 2001;65(3):696-703.

32. Tollner TL, Bevins CL, Cherr GN. Multifunctional glycoprotein DEFB126-a curious story of defensin-clad spermatozoa. Nat Rev Urol. 2012;9(7):365-75.

33. Wu RZ, Hao XM, Liu ZP, Han HS. Sperm motility and ultrastructural changes in blue fox semen before and after freezing. Heilongjiang Animal Science and Veterinary Medicine. 2019:(23):131-134 + 139. (in Chinese)

34. Hancock DC, O'Reilly NJ: Production of polyclonal antibodies in rabbits. In: Burns R, editor. Immunochemical Protocols. Methods Mol Biol; 2005. p. 27-40.

35. Crowther JR. The ELISA guidebook. Methods Mol Biol; 2000.

\section{Publisher's Note}

Springer Nature remains neutral with regard to jurisdictional claims in published maps and institutional affiliations.

Ready to submit your research? Choose BMC and benefit from:

- fast, convenient online submission

- thorough peer review by experienced researchers in your field

- rapid publication on acceptance

- support for research data, including large and complex data types

- gold Open Access which fosters wider collaboration and increased citations

- maximum visibility for your research: over $100 \mathrm{M}$ website views per year

At BMC, research is always in progress.

Learn more biomedcentral.com/submissions 